\title{
Foundation Support Of College Libraries
}

$M r$. Vosper, who is director of libraries at the University of Kansas and prèsident of ACRL, made this address at the ACRL membership meeting at Midwinter on the evening of January 31, 1956.

$\mathrm{T}$ HE recent Ford Foundation grant of $\$ 260,000,000$ particularly for salaries of faculty will provide not only immediate bread-and-butter assistance; it also effectively dramatizes one part of the desperate financial problem faced in these days by privately supported higher education in America.

The recent White House Conference on Education may perhaps bring some federal money to local areas; more importantly, it also focuses greater attention on the financial problems of taxsupported public school education.

In my home town of Lawrence, Kansas, the University rides a hill above the town, and during very recent years we have looked down on the construction of a new high school building and nine grade school buildings in the town and adjacent county. Several years ago from our Mt. Oread we saw flood waters rising from the Kaw River. Now we see a flood of students welling up from the public schools; and the crest of this new flood will inevitably come right into the university buildings in a few more years. The financial problem of tax-supported higher education in America is no less gigantic than that of privately supported higher education or that of public schools.

There is no point in saying more here about the large financial problem all of us in higher education will face during the next two decades and more as enrollments rise rapidly, as the economy continues to be inflated, and as taxation problems at federal and state level are further compounded. You are all aware of this situation.

Let me remind you publicly that the Ford grant for faculty salaries said nothing specific about librarians' salaries, although I presume that a few of our more fortunate colleagues will benefit as the faculty do. Let me further remind you of the hard fact that as the squeeze for operating funds grows greater, many college libraries in this country may well face a serious depression. There will be dramatic campaigns for improved faculty salaries, for student housing, for class room space. But what about books and libraries? I suggest that they will be overlooked in many cases.

My colleagues and $I$ in the research library group will have their own troubles, I am sure, but we already have an active spokesman in the Association of Research Libraries. I urge today that our college libraries also desperately need a spokesman at the national level in regard to this and other critical problems. ACRL must continue to be that spokesman and to an even greater extent than in the past.

Something has already been done. More will be done if we continue to have vigorous and imaginative leadership of the kind Arthur Hamlin has provided; more will be done if ACRL increases its capacity for direct and coordinated action on a large scale in the best interests of American higher education. We are indeed prepared for such a program; we are prepared to state effectively at a national level the problems and needs of college libraries. We are 
already embarked on such a program and at this point we need thoroughgoing support of our full membership if we are to maintain impetus.

At this point we have three special debts to honor. When the United States Steel Foundation made us a $\$ 30,000$ grant last summer, it provided not only money. More importantly, it recognized a basic need in higher education that no other group had perceived. This was an act of imagination and of some faith. Secondly, I want publicly to recognize Librarian Humphrey Bousfield of Brooklyn College, who knew when and where to plant an idea. Thirdly, we are indebted to our executive secretary who has recognized this as a significant development and has worked persistently to assure that the U. S. Steel grant bears further fruit. He saw immediately that we must not only provide stewardship for the U. S. Steel funds but that we must develop a continuing program and turn this first grant into "seed corn."

The actual details of our procedure in alloting the $\$ 30,000$ grant and developing a program have been reported carefully by Mr. Hamlin in a printed statement. ${ }^{1}$ I urge you all to read it. It embodies a dramatic turn in ACRL affairs. I will limit myself to a bit of commentary and reflection.

Already 89 college libraries have received some small tangible benefit. More importantly we have come, with a sense of shock I think, to realize how utterly poverty-stricken are the majority of college libraries in this country. They operate too frequently on a subsistence level or worse, and these libraries are in no position individually to seek substantial outside financial aid.

Here is the problem we must face. I can say here and now that the outlook for the next year is optimistic. Already Mr. Hamlin, acting with initiative and

1 "A Program for Grants to Assist College Libraries, and a Report on the United States Steel Foundation Grant of 1955," Chicago: ACRL, 1956. Available on request from the ACRL headquarters office. under authority given him by the committee, has secured a grant of $\$ 5,000$ from the New York Times. The printed report on the United States Steel grant will suggest the circumstances under which this came to us. Other grants will, I am confident, be forthcoming.

I want to add further that the procurement and handling of foundation funds is not a simple or passive task. The New Yorker has said something in satirical vein about the difficulty of seeking and giving money. I can say sincerely that this task requires positive leadership, vigor, a high level of sophistication, and some statesmanship on the part of our executive secretary and his staff. It also requires hours of hard work. After a year of working closely with your headquarters staff I can assure you that I have complete respect for them and confidence in them.

You will note that the printed report is directed particularly toward industrial and corporate foundations. This reflects a significant change in the complexion of American philanthropy. Organized industrial giving is new and it is burgeoning. It seeks a philosophy of action and a significant area of action in the public interest. We have tried to understand this development, but we certainly do not propose to limit ourselves in the search for aid to college libraries. I assure you that college libraries need all the aid we can bring to them. We seek membership help in getting the official statement into the right hands.

In seeking this aid ACRL needs widespread membership support. Foundations will place funds in our custody only if they are confident that ACRL is a solid, a durable, and an honorable professional organization; only if they are certain that ACRL is indeed the recognized national spokesman for all libraries in American higher education; they will turn to us in confidence only if they are certain that ACRL has a broad base of membership among the profession. 